811.163.41'366.58:811.161.1'366.58

https://doi.org/10.18485/sj.2018.23.1.42

ВЕСНА В. ВУКИЋЕВИЪ*

Универзитет Црне Горе

Филолошки факултет - Никшић
Оригинални научни рад

Примљен: 04. 01. 2018.

Прихваћен: 29. 01. 2018.

\title{
СЦЕНСКИ ПРЕЗЕНТ У РУСКОМ И СРПСКОМ ЈЕЗИКУ
}

У раду се анализира употреба глагола свршеног и глагола несвршеног вида у облику презента у дидаскалијама драмских текстова на руском и српском језику. Анализа се врши на материјалу драма руских и српских писаца краја XX и почетка XXI вијека и њихових превода. Употреба и значења глаголског вида разматрају се у оквиру сажете форме дидаскалија, која би, по претпоставци, могла да утиче на позната значења свршеног и несвршеног вида.

Кључне ријечи: свршени вид, несвршени вид, сценски презент, перфекат, аорист, дидаскалије, драмски текст.

1. По функцији коју имају у тексту дидаскалије представљају упутства глумцима за радње које треба извршити на сцени у вријеме основне сценске радње. Ријетко када се у драмском тексту дидаскалија налази у недвосмисленој форми упутства, али смо у одабраном корпусу драмских текстова уочили и такав примјер.

Толя подходит к Свете, $и$ вот тут она может отойти на другую сторону стола искать домашние тапочки под скатертью.

Тоља прилази Свети, а она би у том тренутку могла да устане и оде на супротни крај стола, трагајући за папучама које се не виде испод столњака. (П Л 30)

"vesnavu@ac.me 
У анализи категорије глаголског вида наведена функција дидаскалија није примарна јер инфинитивна употреба глагола омогућава одабир и једног и другог вида. У руском језику ова конструкција захтијева инфинитив глагола или свршеног или несвршеног вида: должен (может) приоткрыть дверь, должен (может) оттолкнуть ее, должна (может) ударить его. То је једини случај употребе глагола свршеног вида у дидаскалијама руских драмских текстова.

Међутим, поставља се питање да ли управо у функцији упутства може да се нађе језички траг у одабиру глаголског облика у српском језику. Глагол који сада видимо у дидаскалијама на српском језику може да представља дио конструкције којом се дају упутства шта глумац треба да уради или ради на сцени: треба да одикрине врата, треба да одгурне, треба да шутне.

2. За презент у дидаскалијама драмског текста у употреби је термин настоящее сиеническое, сценски презент [Исаченко, 2003: 459; Бондарко, 1971: 72; Војводић, 1989: 92]. А.В. Исаченко наводи да је сценски презент од глагола свршеног вида, за разлику од савременог руског језика, забиљежен у руским драмским текстовима у XVIII вијеку [Исаченко, 2003: 459]. Данас се у руском језику употребљава имперфективни презент, а уколико се жели изразити свршена радња - прошло вријеме глагола свршеног вида.

У српском језику у значењу сценског презента употребљавају се и имперфективни и перфективни глаголи. Сценски презент означава радњу истовремену са неким тренутком сценског времена, а не тренутком говора, па је као такав релативни презент.

Он приоткрывает дверь силой.

Он силом одикрине врата. (П Л 44)

Жанна (вздыхает). Берет...

Жана (уздахне): Жени се... (Р К71)

(Неожиданно - плачет. )

Изненада заплаче. (С К 348)

(садится к Учителю на колени).

Седне Професору у крило. (С К 354)

Входит Жанна. Увидев Веньку, испуганно вскрикивает, но, узнав его, бросается на помощь.

Улази Жана, уплашено крикне, али га препознаје и скаче му у помоћ. (Р К 94)

Направляется в комнату Сына. Вдруг крик. Он останавливается. Выходит Девушка. Кажется, и лицо ее, и руки - все в крови. Она сползает по стене. Падает.

Креће ка синовљевој соби. Одједном крик. Он застане. Излази Девојка. Чини се да су јој и лице и руке обливене крвљу. Она клизи низ зид. Пада. (С К 359)

(Резко отталкивает ее, она ударяет его ногой, он сгибается.)

Оштро је одгурне. Она га иутне, он се увија на поду. (С К 362)

Танька (вздохнула). Маленький ты еще. 
Тања (уздахне): Још си ти мали. (Р К 69)

Рваный. У-у! Полна коробочка. Знакомые все лица! И монах здесь. (Перекре-стился.) Ожиљак: О-о! Пуна кућа! Све позната лица! И калуђер је ту. (Прекрсти се) (Р К 81)

У преводу перфективног презента са српског језика на руски употријебљени су имперфективни презент или прошло вријеме глагола свршеног вида. У случајевима превода имперфективним презентом у руском језику долази до двоструке транспозиције: времена - за прошлу радњу користи се презент; вида - за свршену радњу користи се несвршени вид.

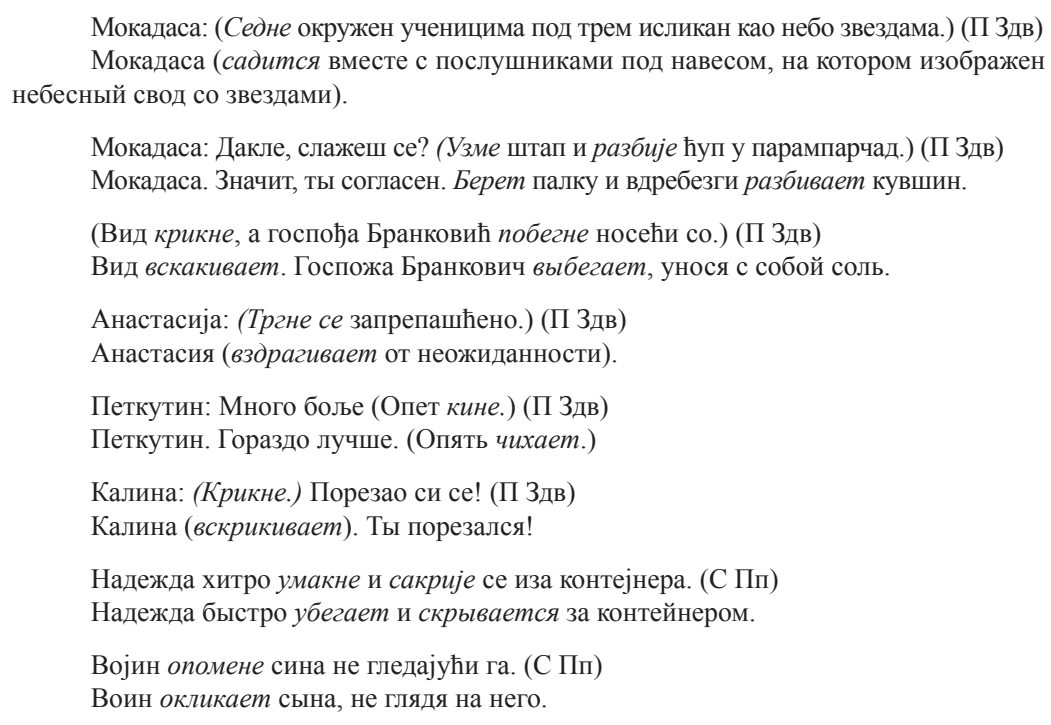

Мокадаса: (Седне окружен ученицима под трем исликан као небо звездама.) (П Здв) Мокадаса (садится вместе с послушниками под навесом, на котором изображен небесный свод со звездами).

Мокадаса: Дакле, слажеш се? (Узме штап и разбије ћуп у парампарчад.) (П Здв)

Мокадаса. Значит, ты согласен. Берет палку и вдребезги разбивает кувшин.

(Вид крикне, а госпођа Бранковић побегне носећи со.) (П Здв)

Вид вскакивает. Госпожа Бранкович выбегает, унося с собой соль.

Анастасија: (Тргне се запрепашћено.) (П Здв)

Анастасия (вздрагивает от неожиданности).

Петкутин: Много боље (Опет кине.) (П Здв)

Петкутин. Гораздо лучше. (Опять чихает.)

Калина: (Крикне.) Порезао си се! (П Здв)

Калина (вскрикивает). Ты порезался!

Надежда хитро умакне и сакрије се иза контејнера. (С Пп)

Надежда быстро убегает и скрывается за контейнером.

Војин опомене сина не гледајући га. (С Пп)

Воин окликает сына, не глядя на него.

Захваљујући могућности употребе и једног и другог вида глагола у презенту у дидаскалијама на српском језику, формирају се богати и изнијансирани низови глагола у којима аутор помјера центар пажње на радње које, по његовој замисли, треба да трају или да се понављају, смјењују у хронолошком слиједу, да нагло отпочну или се заврше. Некада је категорија вида условљена прилошким одредбама (одједном, полако...), а некада се семантиком глагола несвршеног вида ствара дужи временски оквир када се дешавају све остале радње из низа (влада неуобичајено ћутање, почиње да се приближава...) Глаголи несвршеног вида указују на дуже или краће трајање радње (тапка лопту/погађа тањир)

(Одједном прекине у по речи јер у одаји се сви некако чудно држе и влада неуобичајено ћутање.) (П Здв)

(Внезапно замолкает на полуслове, заметив, что все присутствующие держатся как-то необычно. Повисает странное молчание.)

(Петкутин крикне, лајтнант посегне за оружјем и полако почиње да се приближава Петкутину стежући сабљу.) (П Здв) 
Петкутин вскрикивает, лейтенант хватается за оружие и медленно приближается к Петкутину, сжимая в руке саблю.

Милена ућути. Војин чита новине, Андрија тапка лопту. (С Пп)

Милена замолкает. Воин читает газету. Андрия стучит мячом.

Андрија устане од стола, тапка лопту и погађа тањир на столу. Тањир се разбије. Андрија се уплаши. Милена бесно ичикне. (С Пп)

Андрия встает из-за стола, стучит мячом и попадает в тарелку на столе. Тарелка разбивается. Андрия пугается. Милена раздраженно кричит.

Он - резко к ней, завязал рот платком. Она мычит. Он заставляет ее подняться, уводит.

Он се нагло надвије над њом, везује јој уста марамицом. Она покушава да нешто каже. Он је присиљава да устане, одводи је некуда. (С К 346)

2.1. У одређеном броју примјера на српском језику појављује се граматичка подударност облика 3. лица једнине перфективног презента и аориста. Проблем њиховог разграничавања још је израженији када се ови облици нађу у веома сажетом тексту какав је дидаскалија са, у највећем броју случајева, ограниченим контекстом. Оно се може извршити упоређивањем осталих глаголских облика у реченици: ако у дидаскалијама преовладавају облици аориста, може се очекивати да је и споран облик исто аорист - угледа $u x u$ поче да запомаже (аорист) : угледа их и почне да запомаже (презент); љутито устаде и лупи шаком у зид (аорист) : љутито устане и лупи шаком у зид (презент). Дакле, један од начина препознавања глаголског облика је индивидуални стил аутора. Комбинација имперфективног и перфективног презента стандардна је и изражава слијед радњи које се врше. Такође, у комбинацији са перфективним презентом и аорист има јасно изражену употребу, па може да представља одређену врсту оквира за радњу изражену презентом. Осим тога, аористом се у таквим низовима постиже интензификација радње.

(Увидела, завопила.) Рваненький! Что с тобой?

Тања (угледа $u x$, почиње да запомаже): Ожиљчићу! Шта је то са тобом?! (Р К 55)

СЕРГЕЙ. (вдруг встал, стукнул ложкой по стенке, зло).

Сергеј (одједном љутито устаје, лупи шаком у зид) (К ПО 113)

Сын делает несколько шагов - кругом, кругом, маршируя - и возвращается. У него дурашливый вид недоумка.

Син направи неколико корака, у круг, у круг, маршира и враћа се. Прави тупаво лице. (С К 347)

В комнату врывается Иван, падает на колени.

У собу добауља Иван, пада на колена. (К ПО 136)

2.2. О статусу перфективног сценског презента у српском језику доста може рећи велика диспропорција у употреби несвршених и свршених глагола у оригиналним српским драмским текстовима у односу на преводе руских драмских текстова на српски језик. 
У драми Људмиле Петрушевске „Љубав” од преко 30 облика презента само је један преведен перфективним презентом (Он силом одикрине врата) и један прошлим временом глагола свршеног вида (Задумызвается. - Замислио ce.). У драми Људмиле Разумовске „Кући” од преко 180 облика садашњег времена несвршеног вида обликом перфективног презента преведена су свега три глагола. Сличан је случај и са драмом Николаја Кољаде „Полонеза Огињског”. Нешто већи број облика перфективног презента заступљен је у преводу драме „Клинч” Алексеја Слаповског.

Један број глагола у облику презента отпада на глаголе само несвршеног вида, као и на оне које је немогуће било превести њиховим видским парњаком јер би се таквим преводом значајно промијенио смисао реченице. Као преводне еквиваленте конструкција встать на колени, становиться на колени имамо глагол клекнути, без обзира на постојање видског парњака клечати јер то значајно мијења слијед радњи на сцени:

Венька один. Ходит по чердаку, прислушиваясь к ночным звукам. Потом становится на колени и начинает молиться.

Вењка је сам. Хода по тавану, слуша ноћне звуке. Потом клекне и почиње да се моли. (Р К90)

Таня прошла к Диме, встала на колени, боится дотронуться до Димы руками.

Тања му прилази, клекне поред њега, боји се да га додирне. (К ПО 119)

Таня идет к куче бумаг, встала на колени, перебирает листы.

Долази до хрпе папира у углу, клекне, пребира по њима. (К ПО 136)

Он подходит, становится перед ней на колени. Хватает ее за ноги, валит, скручивает, связывает ей руки сзади брючным ремнем.

Он прилази, клекне пред њу. Брзо је ухвати за ноге, обори је, савлада, везује јој руке иза леђа својим каишем. (С К 343)

Танька, Фома и Близнец начинают просить Веньку выпить.

Тања, Фома и Близанац клекну, моле га. (Р К 64)

Перфективни презент је изостао у оним случајевима у којима се могао очекивати у складу са свим правилима употребе перфективног глагола: конкретна свршена радња, неочекиваност радње, наглашена динамика радње. И у случајевима када су у руским примјерима употријебљени глаголи свршеног вида у облику прошлог времена са циљем да се означи завршена радња, тренутна, изненадна радња, у преводу су употријебљени глаголи несвршеног вида. Да би се надомјестило значење неочекиваности, брзине вршења радње, а што се могло изразити глаголом свршеног вида, употријебљене су одговарајуће прилошке одредбе:

Вскочила с пола, распахнула дверь в комнату, в темноту. На мгновение включила свет, тут же выключила, захлопнула дверь. Смотрит на Диму.

Нагло се диже са пода, лупа на врата, улази у мрак. У трену укључује светло, иск/ьучује га, затвара врата, гледа Диму. (К ПО 119) 


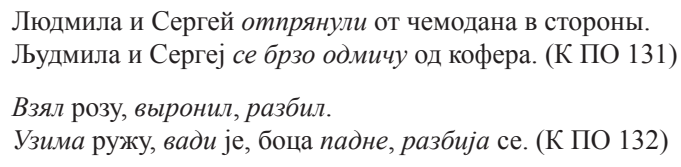

Једини глагол у облику перфективног презента употријебљен је у последњем примјеру - боия, падне - да би се њим истакао кључни моменат у низу радњи на сцени.

3. Сценски презент у руском језику изражава се имперфектнивним презентом, а у српском и имперфективним и перфективним. Уколико је изричита намјера аутора да укаже на резултат радње, динамику дешавања на сцени, смјењивање радњи, онда се у руском језику употребљава прошло вријеме глагола свршеног вида. Уочен је несразмјеран број глагола у облику перфективног презента у оригиналним драмским текстовима писаним на српском језику у односу на преводе руских драмских текстова. Сматрамо да је таква диспропорција посљедица великог утицаја граматичких облика у језику оригинала, а не стилска особеност и изричита намјера преводиоца. Таквим уједначеним одабиром глаголског вида (у корист несвршених глагола) губи се специфична изнијансираност која би се могла постићи низовима глагола различитих видова, а која се јасно уочава у дидаскалијама оригиналних драмских текстова на српском језику.

\section{Извори \\ (са скраћеним ознакама)}

К ПО: Коляда Николай. Поленез Огинского. http://kolyada.ur.ru/polonez/ • Кољада Николај. Полоњеза Огињског. У књ. Гвоздени век (савремена руска драма). Превео Новица Антић. ZEPTER BOOK WORLD. Београд, 2000.

П Л: Петрушевская Людмила. Любовь. http://lib-drama.narod.ru/petrushevskaya/ love.html • Петрушевска Људмила. Љубав. У књ. Гвоздени век (савремена руска драма). Превео Новица Антић. ZEPTER BOOK WORLD. Београд, 2000.

Р Д: Разумовская Люмила. Домой. http://www.theatre.ru/drama/razumovskaja/ domoj_1.html • Разумовска Људмила. Кући. у књ. Гвоздени век (савремена руска драма). Превео Новица Антић. ZЕPTER BOOK WORLD. Београд, 2000.

С К: Слаповский Алексей. Клинч, психологический боевик в 2-х действиях. http://slapovsky.ru/content/view/213/43/ - Слаповски Алексеј. Клинч, психо-акиија у два чина. у књ. Гвоздени век (савремена руска драма). Превео Новица Антић. ZEPTER BOOK WORLD, Београд, 2000. 
С Пп: Србљановић Биљана. Породичне приче. Београд, 1997. http://www. mikaanticforum.org/viewtopic.php?f=26\&t=403 • Срблянович Биляна. Семейные истории. Пьеса в одиннадцати картинах. Перевод Сергея Гирина. Москва, 2002. http://world-play.ru/download/3602.txt

П Здв: Павић Милорад. Заувек и дан више, http://www.rastko.rs/drama/ savremena/mpavic_zauvek_c.html • Павич Милорад. Вечность и еще один день. Перевод Н. Вагаповой и Л. Савельевой. http:// world-play.ru/?page $=$ catalog \&cat $=3595 \& i d=3596$

\section{ЛИТЕРАТУРА}

Бондарко 1971: А. В. Бондарко, Вид и время русского глагола (значение и употребление), Москва, 1971.

Војводић 1989: Дојчил Војводић, Транспозищија перфективног презента у руском и хрватскосрпском језику. Зборник Матице српске за славистику. Књ. 36. Нови Сад, 1989. стр. 85-97.

Исаченко 2003: А. В. Исаченко, Грамматический строй русского языка в сопоставлении с словачким, Морфология, 1-2. Издание второе. Москва, 2003.

Катнић-Бакаршић, Хаџи Пожгај: Марина Катнић-Бакаршић, Весна Хаџи Пожгај, Дидаскалије и сувременој словенској драми. Словенска драматика. стр. 127-135. http://www.centerslo.net/

Катнић-Бакаршић 2003: Марина Катнић-Бакаршић, Стилистика драмског дискурса, Зеница, 2003.

Ковачевић 2000: Милош Ковачевић, Прегнација у ауторској дидаскалији, у: Стилистика и граматика стилских фигура, 3. допуњено и измењено издање, Крагујевац, „Kantakuzin”, 2000.

Thomas 2010: Paul-Luis Thomas, Глаголски облици (,, времена”) у дидаскалијама у: Драма и вријеме - вријеме као драмска тема и драмско средство, форме времена и слике времена, Сарајево, 2010, стр. 141-147. 


\section{НАСТОЯЩЕЕ СЦЕНИЧЕСКОЕ В РУССКОМ И СЕРБСКОМ ЯЗЫКАХ}

\section{Резюме}

В ремарках драматических произведений в русском языке употребляется только настоящее время несовершенного вида, а если нужно передать семантику совершенного вида, то употребляется форма прошедшего времени. В отличие от русского языка, в сербком языке, кроме данных форм, употребляются и формы настоящего времени глаголов совершенного вида. К сожалению, анализ переводов русских драматических произведений на сербский язык в большинстве случаев не показал грамматические и стилистические преимущества данной дополнительной формы.

Ключевые слова: совершенный вид, несовершенный вид, настоящее сценическое, перфект, аорист, ремарки, драматический текст.

Весна В. Вукичевич 